\title{
Nesting and neonates of the yellow-spotted river turtle (Podocnemis unifilis, Podocnemididae) in the Araguari River basin, eastern Amazon, Brazil
}

\author{
Débora Regina dos Santos ARRAES ${ }^{1}$, Marcos TAVARES-DIAS ${ }^{1,2^{*}}$ \\ Universidade Federal do Amapá (UNIFAP), Programa de Pós-Graduação em Biodiversidade Tropical (PPGBI0), Rodovia Juscelino Kubitschek, Km 2, Universidade, 68902-280, \\ Macapá, AP, Brazil. arraesdebora@hotmail.com \\ ${ }^{2}$ Empresa Brasileira de Pesquisa Agropecuária (Embrapa Amapá), Rodovia Juscelino Kubitschek, Km 5, 2600, Universidade, 68903-419, Macapá, AP, Brazil. \\ * Corresponding author: marcos.tavares@embrapa.br
}

\section{ABSTRACT}

Predation and alteration of microhabitats may represent high risk for nesting of Amazonian turtles. This study aimed at investigating the nesting and body parameters of neonates of Podocnemis unifilis in the Araguari River basin, State of Amapá, Brazil. The spawning sites of this turtle were monitored along the Falsino River (a region with two reserves) and in the urban area of the Porto Grande city along the Araguari River, from August to December 2011. A total of 180 nests were found and the nesting occurred from September to November, with prevalence in October. Eggs hatching occurred in December. The mean incubation period was $63.5 \pm 5.2$ days and the eggs hatching success was $25 \%$. However, approximately $80 \%$ of the nests had suffered predation mainly by humans, which occurred in both the protected areas of the reserves and the urban area. The pattern of nesting site choice was discussed. Egg size was larger than that previously described for the same turtle species in the other regions. The body condition index of neonates indicated a good use of vitelline reserves. The results indicate the urgent need for strategic actions to conserve and maintain the natural stocks of this relatively vulnerable turtle in the region.

KEYWORDS: body condition, chelonian, eggs, predation.

\section{Nidificação e neonatos de tracajá (Podocnemis unifilis, Podocnemididae) na bacia do Rio Araguari, Amazônia oriental, Brasil}

\section{RESUMO}

A depredação e alteraçóes do micro-hábitat podem representar grande risco para a nidificação de tartarugas amazônicas. Assim, este estudo investigou a nidificação e características corporais de neonatos de Podocnemis uniflis na bacia do Rio Araguari, estado do Amapá (Brasil). Foram monitorados os locais de desova dessa tartaruga no Rio Falsino (região de duas reservas) e na área urbana da cidade de Porto Grande, no período de agosto a dezembro de 2011 . Foi encontrado um total de 180 ninhos e a nidificação ocorreu de setembro a novembro, mas a maioria ocorrendo em outubro. A eclosão dos ovos ocorreu em dezembro e o tempo médio de incubação foi $63,5 \pm 5,2$ dias, com sucesso de eclosão de $25 \%$. Porém, cerca de $80 \%$ dos ninhos sofreu predação causada principalmente pelo homem, tanto nas áreas protegidas das reservas como na área urbana. O padrão de escolha dos locais de nidificação observado foi discutido. O tamanho dos ovos foi maior que os descritos previamente para essa mesma espécie de tartaruga em outras regiôes. O índice de condição corporal dos neonatos indicou um bom uso das reservas vitelínicas. Os resultados indicam a urgente necessidade de açóes estratégicas para conservação e manutenção dos estoques naturais dessa tartaruga com relativa vulnerabilidade na região.

PALAVRAS-CHAVE: condição corporal, quelônio, ovos, predação. 
The yellow-spotted river turtle (Podocnemis unifilis) inhabits the rivers, streams, lakes and wetlands of the Amazon and Orinoco River basins. This long-lived turtle takes long to reach sexual maturity and has low recruitment in most locations in Amazon (Salera-Júnioret al. 2009). Podocnemis unifilis has a long history of decline due to the use of its meat and eggs by riverine communities, as well as by pressure on its nesting habitats (Smith 1979; Fachín-Terán and Von Mülhen 2003; Coway-Gomez 2007); hence, it is on the global red list of threatened species as vulnerable (IUCN 2012). Therefore, predation mitigation of this Amazonian turtle is a fundamental component in conservation programs. However, such activities when carried out often occur without good understanding of the nesting biology of these aquatic chelonians, whose nests have great risk of predation. The Araguari River basin, in the central region of the State of Amapá (eastern Amazon) is an important area for $P$. unifilis breeding. In this region, deforestation, urban growth, gravel extraction from riverbeds, mining and dam construction are factors that may be influencing the breeding of yellow-spotted river turtle. Thus, this study provided the first investigation on the characteristics of nesting and neonates of $P$. unifilis from the Araguari River basin (Northern Brazil).

In Araguari River basin, the nesting of Podocnemis unifilis Troschel 1848 (Testudines, Podocnemididae) was studied along two stretches (35 km each). The first stretch is located on the Falsino River, within the borders of the Amapá National Forest (Flona, AP) and the State Forest of Amapá (Flota, AP), municipality of Ferreira Gomes. The second stretch is located on the Araguari River, urban area of the municipality of Porto Grande, state of Amapá (Figure 1). From August to December 2011, in monthly visits lasting 10 days each, all possible spawning sites of $P$. unifilis were monitored for identification and registration of their nests (SISBIO: 28856-1). All spawning sites were georeferenced with the Global Positioning System (Garmin, Etrex 30, Kansas, USA) to plot a map with the aid of the program ArcGis 10. With the aid of a tape rule, measurements of length, width and maximum height of the beach in relation to the river were also determined. The vegetation height on the surrounding land was estimated, then defined with three scores: (1) grassy vegetation, regeneration, scattered trees up to $5 \mathrm{~m}$; (2) predominant tree species over 5 and up to $20 \mathrm{~m}$; (3) predominant tree species over $20 \mathrm{~m}$ in height. In addition, the spawning substrates were also classified into four types: sand, gravel, black earth, and dried leaves.

Locating the nests of $P$. unifilis was performed visually from tracks in the sand left by females the night before. Also, with the help of a $15 \mathrm{~cm}$ wooden stick that was inserted into the beach soil, regions were superficially stirred. After observation of the eggs near the soil surface, the nests were again covered (Fachín-Terán 1993). All nests found were georeferenced and labeled with the following information: number of the nest, date and time when the nest was found, geographic coordinates and estimation of the hatching date. Moreover, this identification was performed discreetly and prudently to hinder the rapid discovery of these nests by the public. For this, a marker was kept at $1 \mathrm{~m}$ from each nest found. All nests were measured regarding the distance to the vegetation, distance to the river, and height to the river. After the P. unifilis eggs were laid, the randomly chosen nests were opened for counting the eggs, measuring total depth and opening diameter and determining the total mass, maximum length and maximum width of the eggs. For this procedure, eggs were handled carefully, avoiding rotation or direct exposure to the sun. Successful nests were opened during the hatching stage to check for the clutch size (number of eggs found in each nest), incubation duration, number of live and stillborn neonates, and quantification of unhatched eggs (Camillo et al. 2009).

Upon leaving the nests toward the river, neonates were collected to determine the maximum length of the carapace, maximum width of the carapace, maximum length of the plastron, maximum width of the plastron, carapace-plastron distance, head width, maximum head length, interocular distance, and maximum height of the shell using a manual caliper. The body condition index (BCI) was calculated from the values of maximum carapace length $(\mathrm{cm})$ and body mass $(\mathrm{g})$ and compared to standard values $(\mathrm{BCI}=1.0)$ according to Le-Cren (1951) by using $t$-test $(\mathrm{P}<0.05)$.

From August to December, the mean air temperature was $27.9 \pm 0.3^{\circ} \mathrm{C}$ and mean rainfall was $63.5 \pm 43.1 \mathrm{~mm}$, and this data were obtained from the Center for Hydrometeorology and Renewable Energy (NHMET) at the Institute of Scientific and Technological Research of the State of Amapá (IEPA), respectively.

During the 2011 nesting season, 180 P. uniflis nests were found in the Araguari River basin (Figure 1). In August, only P. unifilis tracks were found on the beaches. The stage of egg-laying began on September 16 and lasted to November 10 , period in which the temperature was high and rainfall decreased in the region. In October, $60.5 \%$ of the nests $(\mathrm{N}=$ 109) were found, indicating the peak of oviposition. Among the nests found in November, $49(94.2 \%)$ were proved to be old (laid at the time interval between field activities), and three were recent, including two laid during the previous nights (days 08 and 09 of November). This indicates that the spawning stage extends up to November. In December, only old nests were found. Similarly, for the same species of turtle from the Curuá River in the State of Pará (eastern Amazon), the nesting period occurred from October to November (Almeida et al. 2005). However, for $P$. unifilis from Javaés River in the state of Tocantins, the nesting period occurred from July to September (Ferreira-Júnior and Castro 2003). In State 


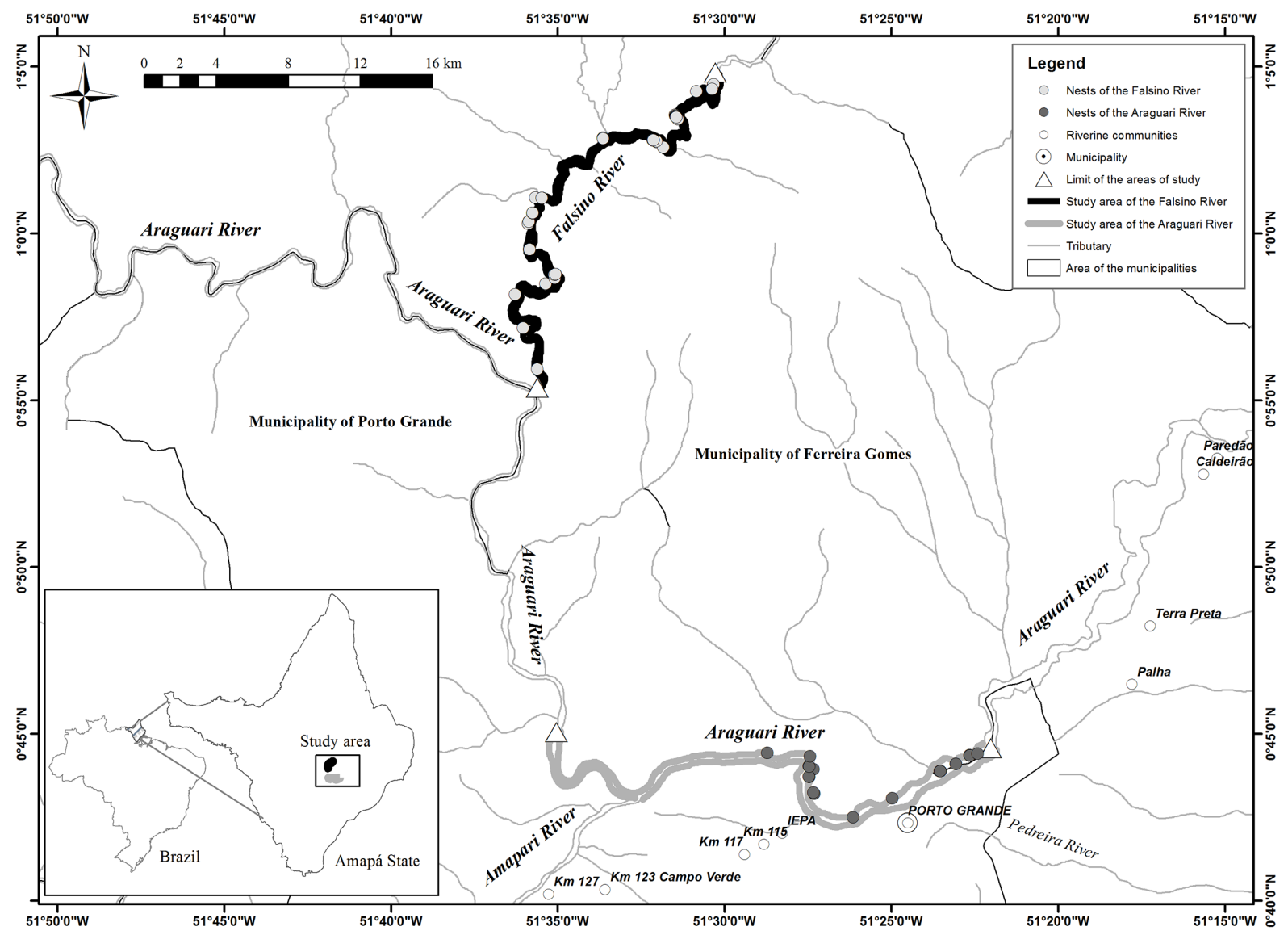

Figure 1. Location map of the study area in the Araguari River basin (eastern Amazon (Brazil), and the distribution and abundance of Podocnemis unifilis nests in 2011.

of Amazonas, the nesting period means the end of August to September on the Japurá and Solimóes Rivers (Fachín-Terán and Von Mülhen 2003) and from August to December on the Purus River (Pantoja-Lima et al. 2009).

For $P$. unifilis from the Araguari River basin in 12 nests, the mean incubation time was $64.5 \pm 6.5$ days varying from 61 to 80 days. Similarly, for the same turtle species from Solimóes River (AM), the mean egg incubation time was 63.5 days (Fachín-Terán and Von Mülhen 2003). Therefore, the spawning and incubation periods occurs during the dry season (from August to November) influenced by the low rainfall, temperature rise, while the eggs hatched at the beginning of the rainy season, with increased river levels. For $P$. uniflis, the incubation temperature influences the embryo development (Fachín-Terán and Von Mülhen 2003) and the birth of hatchlings in rainy season facilitates its access to the river.

In this study, all $P$. unifilis spawning sites were found along the river banks (up to $30 \mathrm{~m}$ from the margin), on islands or on large rocks with a thin layer of sediment, both in the middle of the rivers. Out of these 34 nesting sites, $12 \%(\mathrm{~N}=5)$ showed all measurements between 50 and $210 \mathrm{~m}$ in length, 13 and 100 $\mathrm{m}$ in width, and 1.5 and $4.5 \mathrm{~m}$ in height - a concentration of the majority of nests found $(71.7 \%)$. The mean distance of the nests to vegetation was $2.5 \pm 2.6 \mathrm{~m}$ (0 to $12.7 \mathrm{~m})$, the mean distance of the nests to the river was $5.4 \pm 3.6 \mathrm{~m}(0.2$ to 17.1 $\mathrm{m})$ and the mean height of the nests to the river was $1.1 \pm 0.45$ $\mathrm{m}(0.2$ to $3.5 \mathrm{~m})$. There was a pattern for nesting on beaches that had surrounding vegetation height between 5 and $20 \mathrm{~m}$. At these nesting sites, substrate analysis indicated that $78.3 \%$ of the nests were deposited in sandy environment, $12.8 \%$ in soil with gravel, $6.1 \%$ in dry leaves and $2.7 \%$ on the ground. The type of soil and vegetation are essential factors for habitat and microenvironment of the animals' spawning, as these factors significantly influence the embryo development and neonate success, as well as sex determination and predation rates (Ferreira-Júnior 2009a, b). For P. unifilis from the Purus River (AM), the spawning sites were also close to vegetation in sandy areas and lower beach sites (Pantoja-Lima et al. 2009). However, the type of substrate can influence the hatching time 
of Podocnemis species (Fachín-Terán and Von Mülhen 2003; Ferreira-Júnior and Castro 2003).

To analyze the nests of $P$. unifilis, 23 were opened to measure the inner opening and outer opening of the chamber, mean depth to the first egg, and total mean depth of the chambers, which varied from 12 to $24 \mathrm{~cm}$ (Table 1). A greater nest depth increases the incubation time for eggs of P. unifilis (Ferreira-Júnior and Castro 2003), interfering with the neonates characteristics and vitelline consumption.

In 23 opened nests, seven of them had reproductive success, with a mean of 3.2 eggs per nest without apparent development and 2.87 dead neonates per nest. The hatching was evaluated for 46 nests, considering also those nests that had been preyed upon; out of these, 23 nests were opened soon after eggs were hatched and the other 23 nests were opened while the neonates were leaving the nest. However, the eggs success was low (Table 2). Measurements of diameter and depth of the nests of P. uniflis in this study were similar to those described for this species from Samiria and Loreto River (Fachin-Teran 1993), Solimōes River (Fachín-Terán and Von Mülhen 2003) and Javaés River (Ferreira-Júnior and Castro 2003).

For P. unifilis from Araguari River basin, a total of 324 eggs were found in 23 opened nests, with a loss of 12 eggs during search procedures. The mean number of eggs was $14.0 \pm 6.0$, ranging from 4 to 26 eggs per nest. To evaluate the mean biomass of the eggs, 13 nests were considered (Table 3).This mean number of eggs was lower than in $P$. unifilis from the lower Amazonas River (Pignati and Pezzuti 2012), while the mean egg size was larger compared to this same turtle species from the Samiria River (Fachin-Terán 1993) and Solimōes River (Fachín-Terán and Von Mülhen 2003). However, these distinct results can be directly related to the different size of the breeders from these studies. In general, larger females of P. unifilis produce larger clutches (Pignati and Pezzuti 2012) with larger eggs (Loehret al. 2004; Pignati and Pezzuti 2012) compared to female turtles with lower body mass.

Carapace size and body mass of neonates of $P$. unifilis from the Araguari River basin (Table 4) were similar to those described by Fachín-Terán and Von Mülhen (2003) and higher to those reported by Pignati and Pezzuti (2012) for this same turtle species. BCI values of the neonates (Table 4) did not differ significantly $(\mathrm{t}=10.2, \mathrm{P}<0.05)$ from the standard values $(\mathrm{BCI}=1.0)$, indicating good conditions in the yolk consumption, similar to that described for other turtle species (Loehret al. 2004; Lambrada-Martagón et al. 2010).

Out of the 180 nests found in the Araguari River basin, $20 \%(\mathrm{~N}=36)$ remained intact, while $80 \%(\mathrm{~N}=144)$ had losses. Among these losses, in $75.5 \%(\mathrm{~N}=136)$ of cases the eggs were collected by humans for consumption; $1.7 \%(\mathrm{~N}$ $=3$ ) were lost due to river overflow from flash flooding and $2.7 \%(\mathrm{~N}=5)$ experienced predation by animals, which were observed attacking nests. Such results indicate that the close proximity of $P$. unifilis nesting sites to the riverine and urban communities is the main determining factor for the loss of eggs and consequently, for turtle population density in the region. In addition, the reproductive efficiency of the wild population of $P$. unifilis may be affected by environmental and non-environmental factors. Therefore, reproductive indices data obtained from this study are indispensable for future investigations of impacts on nesting and hatching.

Table 1. Measurements of the nest chambers $(N=23)$ of Podocnemis unifilis in the Araguari River basin, eastern Amazon (Brazil), in 2011. Mean \pm standard deviation (SD)

\begin{tabular}{lll}
\hline Parameters & Mean \pm SD & Minimum-Maximum \\
\hline Diameter of entrance $(\mathrm{cm})$ & $11.4 \pm 2.4$ & $6.0-20.0$ \\
Maximum internal diameter $(\mathrm{cm})$ & $16.2 \pm 2.1$ & $13.9-17.3$ \\
Mean depth $(\mathrm{cm})$ & $6.1 \pm 2.2$ & $4.3-7.8$ \\
Total mean depth $(\mathrm{cm})$ & $18.2 \pm 3.4$ & $12.0-24.0$ \\
\hline
\end{tabular}

Table 2. Mean values and standard deviation of reproductive indices in 46 nests of Podocnemis unifilis from the Araguari River basin, eastern Amazon (Brazil) in 2011.

\begin{tabular}{lll}
\hline Reproductive indices & Number & $(\%)$ \\
\hline Live hatchlings & 161 & 25.0 \\
Dead hatchlings & 138 & 21.3 \\
Unhatched eggs & 138 & 21.3 \\
Eggs losses & 210 & 32.4 \\
Total eggs & 647 & 100 \\
\hline
\end{tabular}

Table 3. Measurements of the eggs and nests of Podocnemis unifilis from the Araguari River basin, eastern Amazon (Brazil) in 2011. Mean \pm standard deviation (SD).

\begin{tabular}{lccc}
\hline Parameters & $\mathrm{N}$ & Mean \pm SD & Minimum -Maximum \\
\hline Body mass $(\mathrm{g})$ & 312 & $26.8 \pm 4.6$ & $15.0-38.2$ \\
Length $(\mathrm{mm})$ & 312 & $47.7 \pm 2.6$ & $40.0-55.0$ \\
Width $(\mathrm{mm})$ & 312 & $30.4 \pm 2.6$ & $24.0-37.0$ \\
Mean biomass of the nests $(\mathrm{g})$ & 13 & $381.5 \pm 178.0$ & $106.8-768.5$ \\
\hline
\end{tabular}


Table 4. Biometric parameters and body condition index $(\mathrm{BCl})$ of neonates of Podocnemis unifilis $(\mathrm{N}=138)$ from the Araguari River basin, eastern Amazon (Brazil) in 2011. Mean \pm standard deviation (SD).

\begin{tabular}{lll}
\hline Parameters & Mean $\pm \mathrm{SD}$ & Minimum-Maximum \\
\hline Body mass $(\mathrm{g})$ & $20.2 \pm 2.5$ & $14.8-24.5$ \\
\hline Carapace length $(\mathrm{mm})$ & $44.8 \pm 4.3$ & $33.0-54.0$ \\
\hline Carapace width $(\mathrm{mm})$ & $38.6 \pm 4.4$ & $25.0-47.0$ \\
\hline Plastron length $(\mathrm{mm})$ & $43.8 \pm 3.0$ & $39.0-53.0$ \\
\hline Plastron width $(\mathrm{mm})$ & $24.5 \pm 3.1$ & $16.0-34.0$ \\
\hline Carapace-plastron distance $(\mathrm{mm})$ & $11.5 \pm 2.7$ & $5.0-18.0$ \\
\hline Head length (mm) & $14.5 \pm 2.5$ & $9.0-21.0$ \\
\hline Head width (mm) & $13.3 \pm 2.4$ & $10.0-19.0$ \\
\hline Interocular distance (mm) & $3.2 \pm 0.8$ & $1.0-6.0$ \\
\hline Maximum shell height (mm) & $25.5 \pm 2.7$ & $17.0-30.0$ \\
\hline Body condition index (BCl) & $0.99 \pm 0.02$ & $0.91-1.06$ \\
\hline
\end{tabular}

\section{ACKNOWLEDGMENTS}

The present work was developed according to the principles adopted by the Brazilian College of Animal Experiments (COBEA). We thank Coordenação de Aperfeiçoamento de Pessoal de Nível Superior (Capes) and Programa de Pesquisa em Biodiversidade (PPBio) for the first atuhor's Masters Scholarship. M. Tavares-Dias was supported by a Research Fellowship from Conselho Nacional de Pesquisa e Desenvolvimento Tecnológico (CNPq).

\section{REFERENCES}

Almeida, S.S.; Pezzuti, J.C.B.; Felix-Silva, D. 2005. Notes on nesting of Podocnemis uniflis (Chelonia: Pelomedusidae) in small agricultural clearings in eastern Amazonia, Caxiuanã, Pará, Brazil. Boletim do Museu Paraense Emílio Goeldi, Série Ciências Naturais, 1: 243-245.

Camillo, C.S.; Romero, R.M.; Leone, L.G.; Batista, R.L.G.; Velozo, R.S.; Nogueira-Filho, S.L.G. 2009. Características da reprodução de tartarugas marinhas (Testudines, Cheloniidae) no litoral sul da Bahia, Brasil. Biota Neotropica, 9: 131-138.

Coway-Gomez, K. 2007. Effects of human settlements on abundance of Podocnemis unifilis and P. expansa turtles in Northeastern Bolivia. Chelonian Conservation and Biology, 6: 199-205.

Fachín-Terán, A. 1993. Caracteristicas de Podocnemis unifilis (Reptilia, Testudines) en el Rio Samiria Loreto. Boletin de Lima, 87: 69-74.
Fachín-Terán, A.; Von Mülhen, E.M. 2003. Reproducción de la taricaya Podocnemis unifilis Troschel 1848 (Testudines: Podocnemididae) en la várzea del medio Solimões, Amazonas, Brasil. Ecologia Aplicada, 2: 125-132.

Ferreira-Júnior, P.D. 2009a. Efeitos de fatores ambientais na reproduçấo de tartarugas. Acta Amazonica, 39: 319-334.

Ferreira-Júnior, P.D. 2009b. Aspectos ecológicos da determinação sexual em tartarugas. Acta Amazonica, 39: 139-154.

Ferreira-Júnior, P.D.; Castro, P.T.A. 2003. Geological control of Podocnemis expansa and Podocnemis unifilis nesting areas in Rio Javaés, Bananal Island, Brazil. Acta Amazonica, 33: 445-468.

IUCN. 2012. Red list of threatened species. Version. Available in:www. iucnredlist. org. Acesso em 25/06/2012.

Lambrada-Martagón, V; Rodriguez, L.C.M.; Gardner, S.C.; Escalona, V.H.C.; Savin, T.Z. 2010. Health indices of the green turtle (Chelonia mydas) along the Pacific coast of Baja California Sur, Mexico. II. Body condition index. Chelonian Conservation and Biology, 9: 173-183.

Le-Cren, E.D. 1951. The lenght-weight relationship and seasonal cycle in gonad and conditions in the perch Perca fluviatilis. Journal of Animal Ecology, 20: 201-219.

Loehr, V.J.T.; Henen, B.T.; Hofmeyr, M.D. 2004. Reproduction of the smallest tortoise, the namaqualand speckled padloper, Homopus signatus signatus. Herpetologica, 60: 444-454.

Pantoja-Lima, J.; Pezzuti, J.C.B.; Teixeira, A.S.; Félix-Silva, D.; Rebêlo, G.H.; Monjeló, L.A.S., et al. 2009. Seleção de locais de desova e sobrevivência de ninhos de quelônios Podocnemis no baixo Rio Purus, Amazonas, Brasil. Revista Colombiana de Ciencia Animal, 1: 37-59.

Pignati, M.T.; Pezzuti, J.C.B. 2012. Alometria reprodutiva de Podocnemis unifilis (Testudines: Podocnemididae) na várzea do baixo Rio Amazonas, Santarém, Pará, Brasil. Iheringia, Série Zoologia, 102:48-55.

Salera-Júnior, G.; Malvasio, A.; Portelinha, T.C.G. 2009. Avaliação da predação de Podocnemis expansa e Podocnemis unifilis (Testudines, Podocnemididae) no Rio Javaés, Tocantins. Acta Amazonica; 39: 207-214.

Smith, N.J.H. 1979. Quelônios aquáticos da Amazônia: um recurso ameaçado. Acta Amazonica, 9: 87-97.

Recebido em 11/06/2013

Aceito em 11/09/2013 
